\title{
EPIPHREATIC CAVES IN NIAH KARST TOWER (NW BORNEO): OCCURRENCE, MORPHOLOGY AND HYDROGEOCHEMISTRY
}

\author{
JAME EPIFREATIČNE CONE V KRAŠKEM STOLPU NIAH \\ (SEVEROZAHODNI BORNEO): POJAVNOST, MORFOLOGIJA \\ IN HIDROGEOKEMIJA
}

\author{
D. DODGE-WAN ${ }^{1 *}$, M.V. PRASANNA ${ }^{1}$, R. NAGARAJAN ${ }^{1} \&$ A. ANANDKUMAR ${ }^{1}$
}

\begin{abstract}
UDC 551.444(595.43)

D. Dodge-Wan, M.V. Prasanna, R. Nagarajan \& A. Anandkumar: Epiphreatic caves in Niah karst tower (NW Borneo): occurrence, morphology and hydrogeochemistry

Epiphreatic caves develop close to the water table at the boundary between vadose and phreatic karst zones. The recognition of their former existence and position in uplifted limestone regions can inform on phases of uplift, base level lowering and rate of vertical deepening of the karst. Hence, epiphreatic caves and the karst processes that form them are of specific interest. Although the large and spectacular caves of Niah have been subject of much research and interest, the existence of small epiphreatic caves at the foot of the karst towers has not previously been documented in this region of NW Borneo. The study documents and reports an epiphreatic cave passage at water table elevation in the Painted Cave karst tower where several large caves are also known. The semi-flooded passage is over $480 \mathrm{~m}$ long and traverses the tower from east to west, intersecting other much larger vadose caves. The epiphreatic flow path is characterized by a number of sinking streams and resurgences as well as several sharp bends in the passage indicating joint control. As an initial attempt this study was undertaken to correlate the water chemistry along the cave path to understand the geomorphological controls. A preliminary campaign of water sampling was carried out with samples collected at ten locations along the path of the cave stream and analyzed for $\mathrm{pH}, \mathrm{EC}$, TDS, DO, Eh, major ions, nutrients and trace metals. The results show that dissolution of host rock and leaching of organic matter are the dominant controlling factors for the geochemistry of surface water along the cave stream passage. During dry conditions the water was under-saturated for carbonate minerals but not aggressive suggesting that most dissolution and erosion occurs during flood conditions. This is supported by the morphology of the passages and features of the rock wall both inside the caves and at the foot of the karst tower.
\end{abstract}

Key words: Karst, Niah cave, Epiphreatic, Hydrogeochemistry, water table.

Izvleček

UDK 551.444(595.43)

D. Dodge-Wan, M.V. Prasanna, R. Nagarajan \& A. Anandkumar: Jame epifreatične cone $v$ kraškem stolpu Niah (severozahodni Borneo): pojavnost, morfologija in hidrogeokemija

Epifratične jame nastajajo na meji med vadozno in freatično cono. Prepoznavanje epifreatičnih elementov v bloku dvignjenega masiva nam omogoča razbrati faze dvigovanja masiva oz. spuščanja erozijske baze, zato so epifreatične jame in procesi še posebno zanimivi. Čeprav so o jamah stolpa Niah opravili številne študije, nobena od teh ne obravnava epifreatičnih jam ob vznožju kraškega stolpa. Ta študija obravnava epifreatične rove na ravni vodne gladine v stolpu Painted Cave v severozahodnem Borneu, kjer sicer poznamo več velikih jam. Delno potopljen rov je dolg več kot $480 \mathrm{~m}$ in preči stolp od vzhoda proti zahodu ter pri tem seka še več drugih, veliko večjih vadoznih jam. Epifreatični tok je povezan $z$ več ponikalnicami in izviri, zanj so značilne nagle spremembe smeri, ki sledi vodilnim razpokam. Namen študije je povezati kemijo vode vzdolž toka in aktivne geomorfološke dejavnike. Vzorčenje in analize vode na desetih lokacijah so dali podatke o $\mathrm{pH}$, električni prevodnosti, skupni raztopljeni snovi (TDS), raztopljenem kisiku, Eh ter o koncentraciji glavnih ionov, hranil in kovin v sledeh. Rezultati so pokazali, da sta raztapljanje matične kamnine in izpiranje organskih snovi prevladujoča dejavnika geokemije vode v kanalu. V sušnem obdobju je voda rahlo nenasičena na kalcit, a je agresivnost majhna, kar kaže na to, da glavna faza razvoja poteka v poplavnih obdobjih. To potrjujejo tudi morfologija rova in jamske skalne oblike v jami in ob vznožju kraškega stolpa.

Ključne besede: kras, jama Niah, epifreatična cona, hidrogeokemija, vodna površina.

${ }^{1}$ Department of Applied Geology, Faculty of Engineering and Science, Curtin University Malaysia, CDT 250, 98009 Miri,

Sarawak, Malaysia.E-mail: dominique@curtin.edu.my; prasanna@curtin.edu.my; nagarajan@curtin.edu.my;

anand2explore@gmail.com

*Corresponding author email: dominique@curtin.edu.my; Tel: + 6085 443824; Fax: + 6085443837

Received/Prejeto: 09.02.2017 


\section{INTRODUCTION}

Epiphreatic cave passages develop in the transition zone between vadose and phreatic groundwater flow. Cave passages in the vadose zone, above the water table, may be dry or partially filled with gravitational groundwater flow depending on recharge. Passages in the phreatic zone are entirely water-filled (full pipe flow) and may sometimes extend deeply below the water table in phreatic loops formed along routes of greatest hydraulic efficiency (Ford \& Ewers 1978; Ford \& Williams 2007; Palmer 1991). The epiphreatic zone is characterized by fluctuations in the water table and epiphreatic passages reportedly develop mostly by floodwater flow as floodwaters are more corrosive and erosive than low waters (Gabrovsek et al., 2014; Frumkin 2013). Epiphreatic cave passage development is generally considered to be favored in situations where there is a high frequency of permeable fissures (Ford \& Ewers 1978) and static fluvial base levels allowing for conduit development close to the water table. It follows that epiphreatic cave passages are useful indicators of geomorphic history of a karst region although relatively under-studied particularly in tropical karsts. Epiphreatic cave passages have not been previously described in this karst region of Borneo.
Cave systems are subjected to different physical and chemical processes, which are controlled by a variety of parameters like temperature, air circulation, $\mathrm{CO}_{2}$ pressure, oxygen partial pressure, wall rock geology and chemical composition of cave water (White 1997). The hydrogeochemical characteristics of cave waters indicate the carbonate dissolution and the formation of speleothems (Holland et al. 1964; Gonzales et al. 1992; Prasanna et al. 2014a). Few cave water studies were focused on the water flow condition in the karstic aquifers (Kogovsek 1997; Motyka et al. 2001); water rock interaction between the rainwater chemistry and carbonate bedrock (Borsato 1997; Motyka et al. 2002; Tooth \& Fairchild 2003; Musgrove \& Banner 2004); cave water quality by various pollution sources (Goc et al. 2000; Motyka \& Rozkowski 2002; Neill et al. 2004). Hence, the present study aimed to map the epiphreatic features in a relatively small karst tower, to document their position, size and orientation, particularly with regards to jointing and location of sinks and springs which had not previously been reported at Niah. This study also aimed to determine the hydrochemical behavior of Niah epiphreatic cave stream and its controlling factors during a dry season.

\section{STUDY AREA}

The study area belongs to one of the most significant karst areas in northern Sarawak (Malaysia) located in Niah National Park in the low lying coastal region between Miri and Bintulu (Fig. 1). The area is characterized by a number of karst towers emerging from the surrounding swampy alluvial plain. Of these the Great Cave tower and the Painted Cave tower are the most accessible, being equipped with timber walkways for visitors. Niah Great Cave, or Gua Niah, is the largest cave and one of Sarawak's key tourist attractions. The caves are renowned for the long-established tradition of harvesting swiftlet nests from the cave ceilings as well as for their archeological significance, which includes human remains dated 35,000 BP (Barker et al. 2007; Stephens et al. 2017). The caves are also home to large colonies of numerous bat species (Leh \& Kheng 2001). The Great Cave is complex with several large wide passages, high chambers with picturesque ceiling openings. The cave's guano deposits contain a record of regional paleo-environmental conditions possibly extending back at least $55 \mathrm{ka}$ (Stephens et al. 2017). There are over six entrances opening on various sides of the limestone hill.
This study focusses on caves formed in a smaller karst tower located to the southeast of the Great Cave hill and visible from the Gan Kira entrance of the Great Cave (Fig. 2). The smaller karst tower contains the wellknown Painted Cave, or Gua Kain Hitam $\left(3^{\circ} 48.651 N\right.$, $\left.113^{\circ} 47.193 \mathrm{E}\right)$. Several caves are developed in this tower at various levels as shown on Fig. 2 and described here, from highest to lowest. In the uppermost levels of the tower, there are cave entrances located high above the forest canopy. These caves, with high ceiling fissures, were not mapped but are known to be the site of birdnest harvesting activities. In the middle levels of the tower, lie the largest caves. The main and best known is the Upper Painted Cave (or Painted Cave), famous for its cave wall paintings as well as boat burials and other artifacts (Pyatt et al. 2005). It is approximately $60 \mathrm{~m}$ wide, up to $40 \mathrm{~m}$ high and $120 \mathrm{~m}$ long sub-horizontal passage which runs through the tower from northwest to southeast (Dodge-Wan et al. 2012). The passage floor is located between $30 \mathrm{~m}$ and $15 \mathrm{~m}$ above the surrounding alluvial plain. The cave floor slopes down towards the lower south entrance. There are cave sediment deposits, 
ceiling breakdown blocks and numerous speleothems including biologically influenced crayback and craybacklike stalagmites and tufaceous stalactites (Lundberg \& McFarlane 2011; Dodge-Wan et al. 2012; Dodge-Wan \& Deng 2013). At lower levels in the karst tower, there are other large cave passages, including the Lower Painted Cave, a canyon-like vadose passage over $10 \mathrm{~m}$ wide and $16 \mathrm{~m}$ high with two large entrances in the west face of the tower at alluvial plain level (Fig. 2). The passage has stacked wall notches and thick mud and guano deposits. The epiphreatic passages described for the first time in this study are the lowest accessible level of cave at Niah and reflect the most recent and on-going phase of karstification. They are located at the foot of steep cliffs in the karst towers and intersect the older vadose passages of the Lower Painted Cave.

The limestone is of early Miocene age (Hutchison 2005) and is massively bedded, homogenous and of algal-coral reefal facies with no interbedded mudstones. The beds are subhorizontal and stylolites are very common. The limestone belongs to the Subis Limestone Member of the Tangap Formation and is surrounded by country rock of the Setap Shale Formation (Hutchison 2005). The highest limestone outcrops in Niah rise over
$390 \mathrm{~m}$ above the surrounding low lying plain, and several hundred meters thickness of limestone is reported below ground level (Hutchison 2005). Karstification occurred in five identified phases of Pleistocene to Recent age related to successive changes in uplift and eustatic sea level (Wall 1967). This lead to the present situation with cave passages at several different levels in the uplifted rock mass. In some of the relict upper cave passages at Niah, such as the Traders' Cave, vadose alluvial notches provide evidence of paleo water levels between 55.5 and 40 $\mathrm{m}$ above the present sea level (Dodge-Wan 2017). Dating of sediments from caves in Mulu, $120 \mathrm{~km}$ north east of Niah, has provided epirogenic uplift rates of $0.19 \mathrm{~m} / \mathrm{ka}$ and indicates strong link between incision and isostatic uplift (Farrant et al. 1995).

The climate is tropical, with temperatures averaging $27^{\circ} \mathrm{C}$ and annual average rainfall is $2794 \mathrm{~mm}$ from 29 years monthly average data (1983-2011). The monsoon average rainfall is $2305 \mathrm{~mm}$, whereas the post monsoon average is $1056 \mathrm{~mm}$ (Niah National Park Headquarters, Lat. $3^{\circ} 49.5 \mathrm{~N}$, Long. $\left.113^{\circ} 45.7 \mathrm{E}\right)$. Vegetation is mixed dipterocarp forest with swampy riverine forest in the lowlands.

\section{METHODS AND MATERIALS}

\section{SURVEYING}

A foot traverse survey in the swampy forest around the circumference of the Painted Cave tower was conducted. Survey measurements were made using Bosch hand-held laser distance meter and Silva compass. The larger more accessible caves (Upper and Lower Painted Cave) were surveyed in a similar manner using tripod based stations and sections of the cave map were published previously by Dodge-Wan et al. (2012).The survey included approximately 200 stations above and below ground including 7 survey loops. Survey data was processed with "Compass" cave mapping software, including correction for loop closure, georeferencing with four fixed stations and calculation of all station UTM coordinates. In order to improve on irregular GPS signal under the forest canopy and adjacent to the karst tower multiple readings were made at several fixed stations over a period of time. Accuracy of Upper and Lower Painted cave and karst tower perimeter surveying is grade 4B (Häuselmann 2011). Due to flooding risk and other dangers, epiphreatic cave network was not fully mapped but the orientation and approximate dimensions of accessible cave passages were measured or estimated. Plotting was carried out using AutoCAD with the station coordinates, field sketches and data.

\section{WATER SAMPLING AND TESTING}

Ten water samples were collected along the path of the cave stream on $29^{\text {th }}$ March 2014 between 9.00 a.m. to 5.00 p.m. from upstream to downstream. Sample locations are shown on Fig. 1. pH, electrical conductivity (EC), total dissolved solids (TDS), dissolved oxygen (DO), oxidation-reduction potential (Eh) were measured in the field using portable $\mathrm{pH}$ and conductivity meter (Thermo Scientific Orion Star, 4 Star Plus Meter). The collected samples were preserved by acidifying to $\mathrm{pH}$ $\sim 2$ with $\mathrm{HNO}_{3}$ for trace metal analyses. Calcium $\left(\mathrm{Ca}^{2+}\right)$, Magnesium $\left(\mathrm{Mg}^{2+}\right)$, Bicarbonate $\left(\mathrm{HCO}_{3}^{-}\right)$and chloride $\left(\mathrm{Cl}^{-}\right)$were measured using titrimetric method (APHA 1995). Nutrients were analyzed using Hack Test Kits (Nitrate $\left(\mathrm{NO}_{3}^{-}\right)$- Cadmium Reduction method, Ammonia $\left(\mathrm{NH}_{3}\right)$ - Salicylate method, Phosphate $\left(\mathrm{PO}_{4}^{3-}\right)$ - Ascorbic acid method, Sulfate $\left(\mathrm{SO}_{4}^{2-}\right)$ - SulfaVer 4 method). Trace metals $(\mathrm{Cu}, \mathrm{Pb}, \mathrm{Fe}, \mathrm{Mn}, \mathrm{Zn}, \mathrm{Cd}, \mathrm{Ni}$ and $\mathrm{Co})$ were determined using Atomic Absorption Spectrophotometer (Perkin Elmer Analyst 400). The bias and variability of 
data was cross checked by the quality control and quality assurance samples. Analytical precision was $\pm 5 \%$ for all trace metals. Saturation Index (SI) of carbonate minerals, Carbonate dioxide partial pressure $\left(\log \mathrm{pCO}_{2}\right)$ and ionic strength (IS) were computed using WATEQ4F program (Ball \& Nordstrom 2001; Chidambaram et al. 2012). Pearson's correlation matrix and Principal component analysis was carried out using SPSS software (version 9.0 for Windows).

\section{STREAM FLOW RATE}

Stream flow rate during drought conditions was approximated by measurement of cross-section and timing of float movement at one sample site (point 3). At other sampling sites, flow was observed and qualified as either "visible" or "slight". No observation of flood flow rates has been made to date.

\section{RESULTS AND DISCUSSION}

\section{TOWER AND CAVE MORPHOLOGY, FEATURES AND FORMATION}

The summit of the Painted Cave karst tower is approximately $110 \mathrm{~m}$ above the surrounding swampy plain. During much of the year the ground around the tower is swampy with water levels at or above ground level in many places. The foot of the tower, mapped in detail for the first time here, has a roughly triangular shape in map view (Fig. 1). There are large fallen blocks and breakdown debris in several places adjacent to the limestone outcrop which is approximately $300 \mathrm{~m}$ diameter. In several locations around the foot of the tower there are ruiniform karren pinnacles separated by narrow jointcontrolled corridors. The ruiniform rocks have been preferentially eroded along the numerous subhorizontal stylolites, giving them an irregularly layered, coarse "pancake-stack" appearance (Fig. 3). Erosion and widening of the stylolites is a subaerial process which appears to be biologically mediated. The rocks are covered with dark biofilms, mosses and lichen. Microfissures along stylolites are preferential rooting zones for these plants and larger joints are penetrated by roots and lianas of higher plants including large trees. The lowest 1 to $1.5 \mathrm{~m}$ of rock surface is below water during the frequent moderately wet to flood conditions. This surface is generally lighter coloured, smooth and moderately scalloped, with no stylolite erosion (Fig. 3). There is a small swamp notch approximately $0.8 \mathrm{~m}$ high and in places this may be a trace of former epiphreatic tube passage that has been exposed due to cliff breakdown. There are also decimeter-sized cavities at ground level where rock meets soil and leaf litter. These are only exposed during drought conditions and most of the time they are submerged. An additional relict swamp notch is noted in places approximately $2 \mathrm{~m}$ above ground level, with smooth, scalloped rock, and no stylolite erosion. It is thought to represent a former phase of erosion linked to a period when base level was higher than at present. The fact that it is not showing preferential stylolite erosion suggests that it is relatively recent.

The epiphreatic cave passages are very much smaller than any of the other caves in the karst tower being less than $2 \mathrm{~m}$ diameter. They are located at the water table i.e. close to the ground level of surrounding alluvial plain. They are simple tube-like passages that are totally flooded during wet periods and approximately half-filled with stagnant water during long dry periods (Fig. 4). In map view the epiphreatic tube passages follows a $480 \mathrm{~m}$ long zigzag path through the tower and the presence of joints in the ceiling in several places suggests that passage formation is initially controlled by jointing in the strong rock (Fig. 1). Where the allogenic stream first sinks into the limestone on the east side of the tower (point 2) it follows an approximately east to west path into the rock mass, whereas further downstream it clearly follows a NNW-SSE oriented joint. After several turns, resurgences and sinks, the stream intersects and flows perpendicularly across the Lower Painted Cave vadose canyon where it has eroded a channel in the cave sediment. The flow eventually emerges at a small resurgence on the northwest side of the karst tower (point 9). The contorted path taken by the stream through the tower from the initial sink to the final resurgence is twice as long as the straight line distance. Approximately $90 \%$ of that path is underground and 10 $\%$ is outside the tower and exposed to daylight. In three places the rock above the epiphreatic passage has eroded or collapsed, forming a skylight or access point (Fig. 4). No other discrete allogenic streams or penetrable cave passages were noted at swamp level when surveying the tower circumference.

The cross-section profile of the passage is generally oval and widest in horizontal direction, with some indication of vadose notch formation overprinting the essentially phreatic oval shape (Figs. 4 and 5). Height of tube is approximately 1 to $1.5 \mathrm{~m}$. The cave walls are gen- 


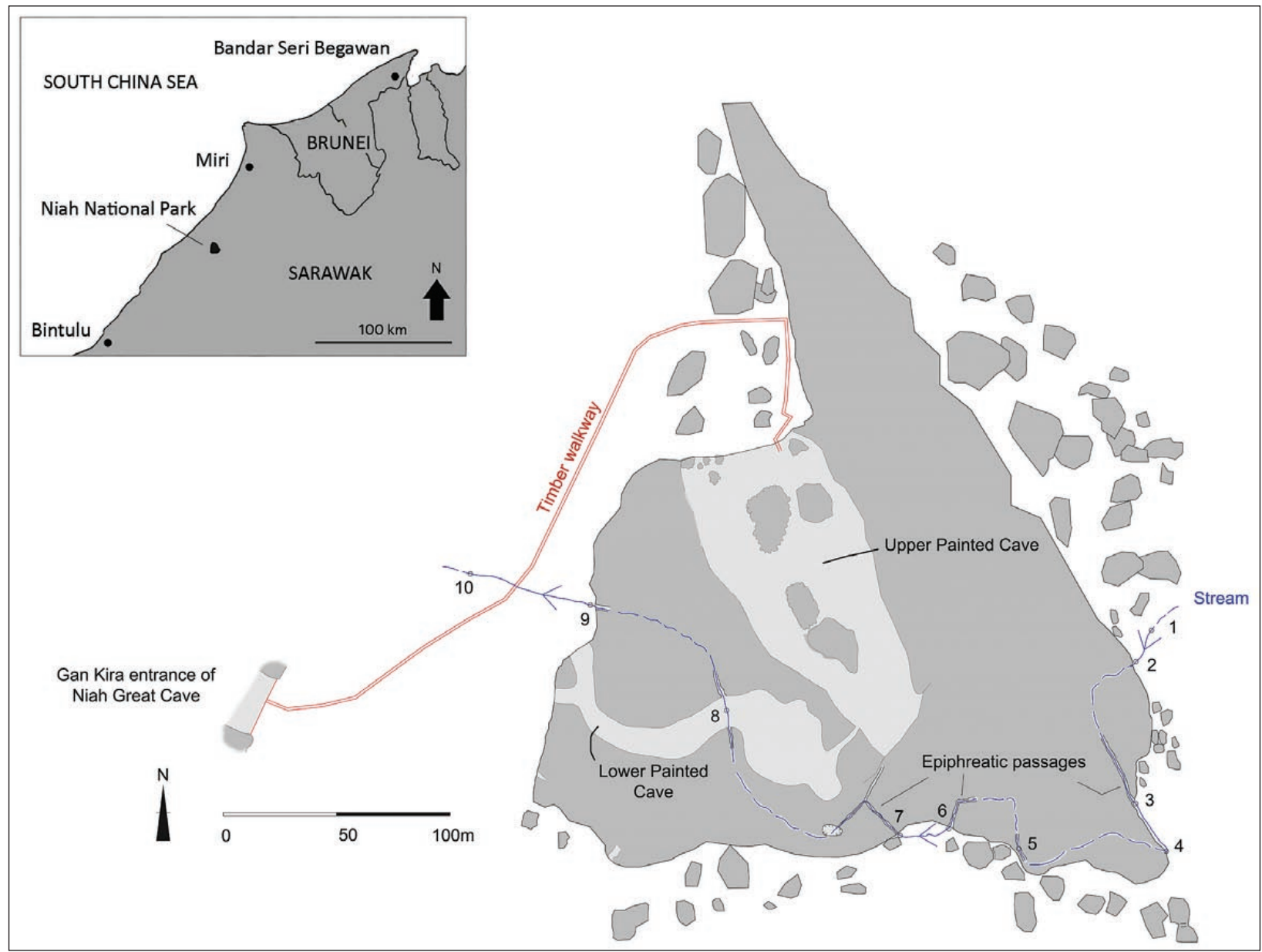

Fig. 1: Location map showing Painted Cave karst tower, Upper and Lower Painted Cave passages, epiphreatic cave passages and water sampling points (numbered 1 to 10). The swampy ground around the base of the tower is approximately $20 \mathrm{~m}$ above sea-level. Dark grey denotes limestone tower outcrop above ground level and approximate position of large fallen limestone blocks around the tower, light grey denotes surveyed cave passages. Niah Great cave tower: only position of Gan Kira entrance is shown.

erally scalloped and sharp rock protrusions are observed at floor or at ceiling level (rock pendants). Adjacent scallops may have sharp cuspate boundaries. The ceilings commonly show evidence of sub-vertical jointing, with some joint enlargement and half-tube formation following the joints. Irregular remnant pillars of bedrock, spanning from ceiling to floor, are observed in places. They also have scalloped surfaces and sharp edges. In the scalloped cave walls, bedrock stylolites are not preferentially eroded, contrary to the subaerially exposed limestones outside the caves. In the cave walls, there is no evidence of preferential erosion of any beds due to lithological variations. The rock appears to be strong and homogenous throughout with no mudstone or other soft rock interbeds.

No evidence of carbonate mineral precipitation or speleothems was observed in the epiphreatic passage. However, small tufaceous stalactites (external speleothems) were noted in some entrance locations exposed to the daylight (point 6). Both organic matter and clay sediments are common in the epiphreatic passage. Organic matter consists of leaves and woody plant debris washed in with the flow, floated in and fallen in from open ceiling skylights as well as live plant roots and lianas which penetrate rock joints. Clay sediments form small accumulations (less than $30 \mathrm{~cm}$ thick) on cave wall ledges and in the bottom of the stream. Soft clay sediment is abundant where the epiphreatic passage intersects the Lower Painted Cave (point 8).

At the time of dry season sampling, the stream in the epiphreatic cave was qualified as having slow but visible flow at points 1, 2, 3, 9 and 10. At point 3 flow rate measured by cross-section and surface velocity was found to be $5-10 \mathrm{l} / \mathrm{s}$. At points 4 to 8 which are in the central part of the stream's path through the karst, the flow rate was qualified as slight. The water samples can therefore be considered as samples from the top of a very slow moving water table during low flow conditions, 


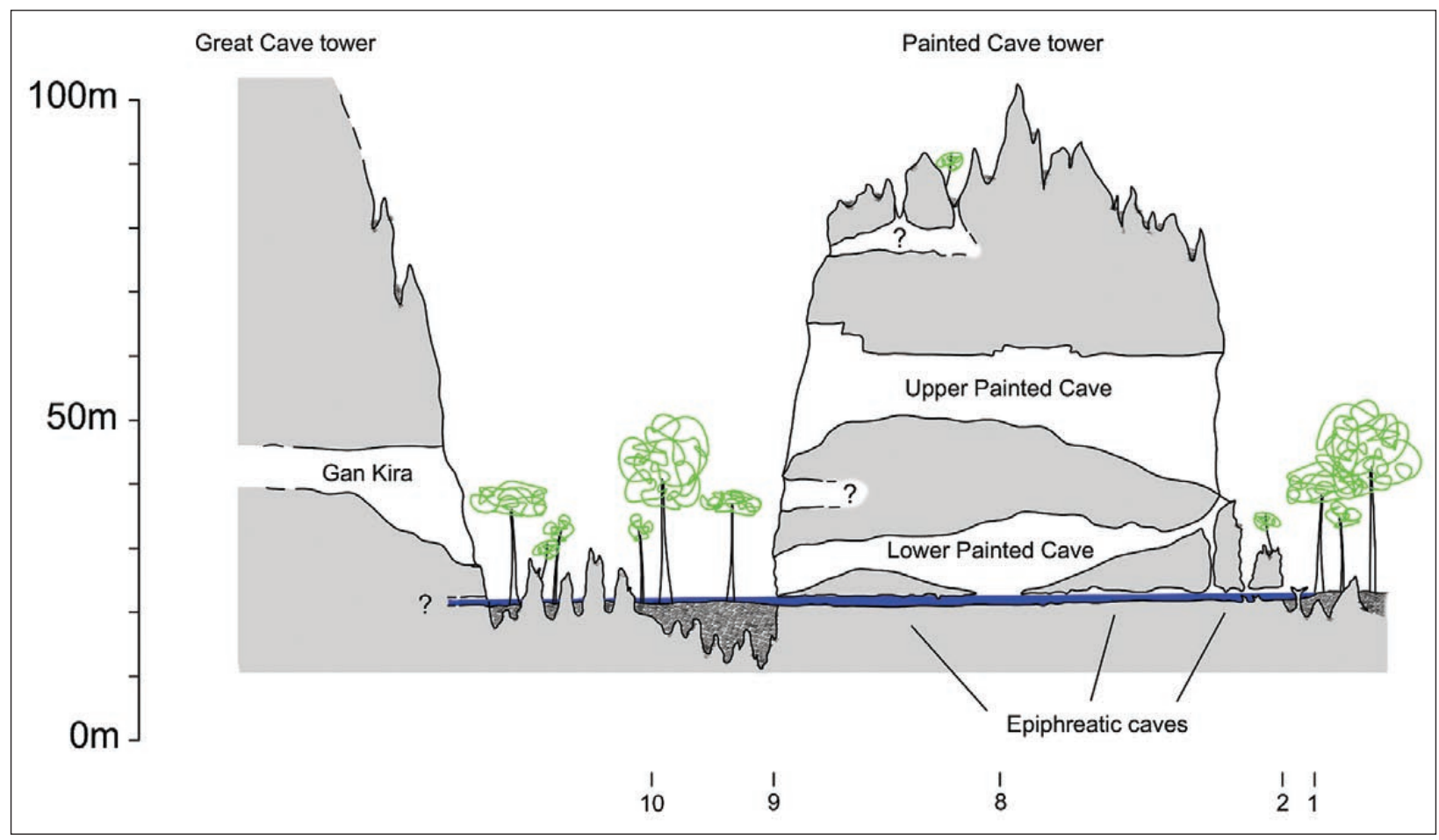

Fig. 2: Schematic cross-section approximately NW (Great Cave tower) to SE (Painted Cave tower) illustrating the relative position of cave passages at four different elevations in the Painted Cave karst tower, with epiphreatic caves at swamp level. Vertical scale bar refers to elevations in meters above sea level. Figure is not to scale horizontally. Flow is from right to left and numbers at bottom of figure refer to selected sample positions. Grey represents limestone and speckled hatching represents sediments and organic matter.

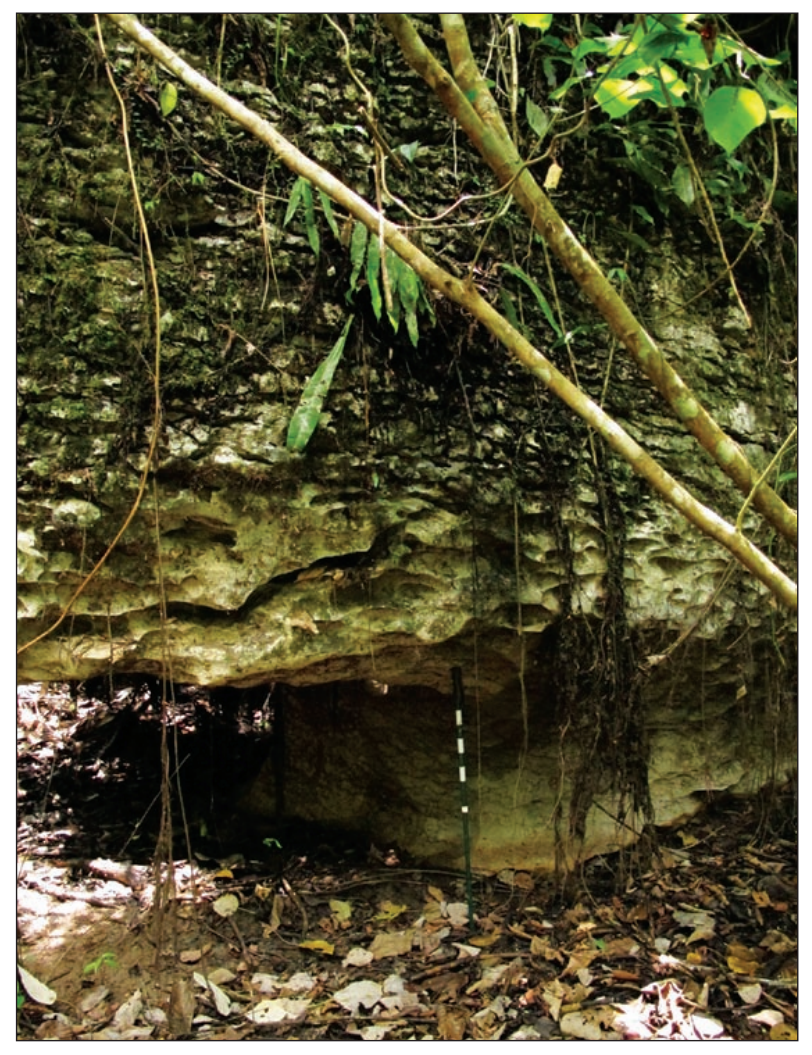

rather than samples from a fast flowing underground stream. The maximum discharge rate is not known, but can be expected to be one or more orders of magnitude greater than the above value. During floods, the entire swampy valley bottom adjacent to the karst towers may be submerged to over $1 \mathrm{~m}$ above ground level.

Wall (1967) had suggested that many passages of the Niah caves were probably initiated in the phreatic zone along joints and bedding planes and later enlarged in the vadose zone. The epiphreatic passages are evidence of similar cave initiation and enlargement in the recent geological past and on-going today, primarily along joints. No evidence of bedding plane erosion, such as preferential widening or enlargement at a specific bed level, was observed. The predominant joint orientation

Fig. 3: Morphology of limestone at foot of karst tower south of sampling point 4, showing smooth scalloped swamp notch (behind walking stick) and irregular erosion of stylolites in rock face higher up where it is covered in biofilms. Stylolites are visible in the rock to right of foot of walking stick, but in the lower frequently flooded section they have not been eroded. Large white bands on stick are $5 \mathrm{~cm}$ long. Photo taken during drought conditions (March 2014) (Photo by: D. Dodge-Wan). 


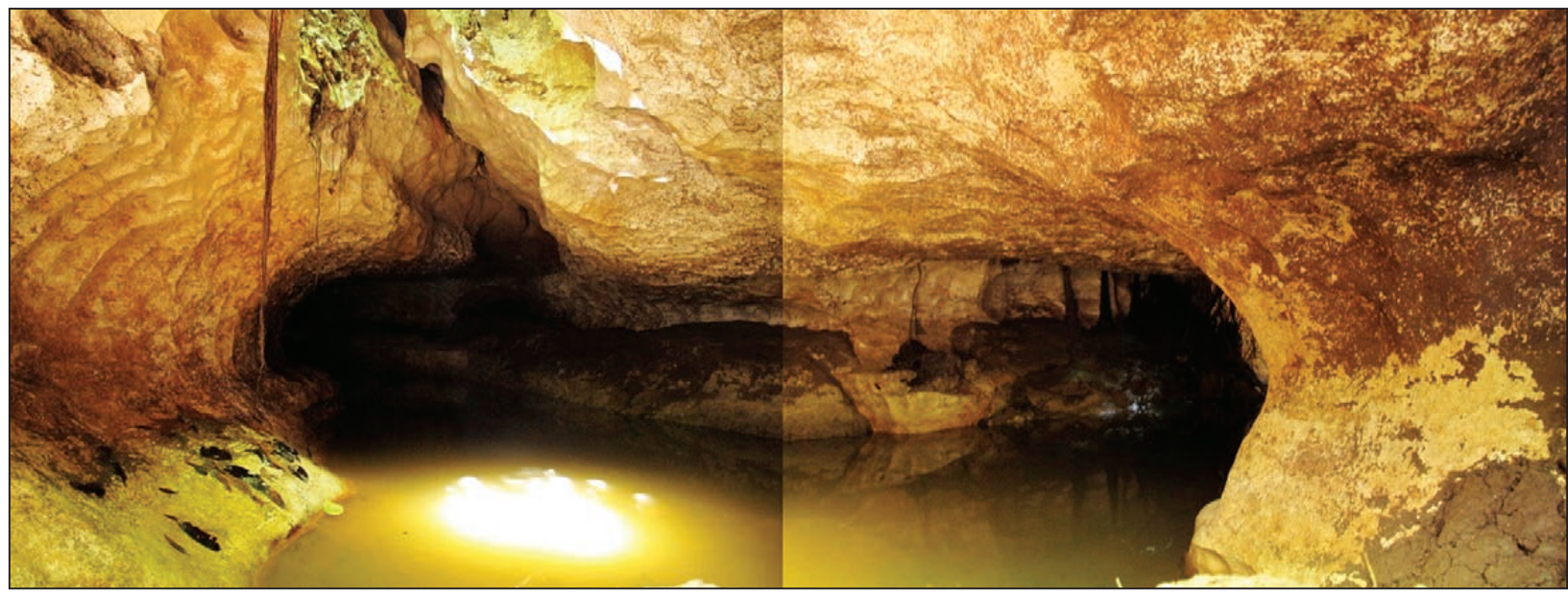

Fig. 4: Montage of two photos of epiphreatic cave passage at sample point 5 where passage forms a joint controlled angle. Flow is from right to left but water was almost static at time of observation (drought conditions). Note presence of wall scallops and joint in ceiling of both passages (most clear on left photo) with ceiling half tube approximately $1 \mathrm{~m}$ above water level. Note also ceiling opening on left with plant roots and leaf debris fallen into cave as well as clay sediments in places on rock ledges (Photo by: D. Dodge-Wan).

is NNW-SSE (between $140^{\circ}$ and $180^{\circ}$ ). In all, $54 \%$ of the $147 \mathrm{~m}$ of surveyed epiphreatic passages align with this joint orientation, with flow direction alternatively towards NNW or towards SSE depending on the position along the contorted flow path through the tower. Between points 3 and 4 flow direction is towards SSE, and the joint orientation observed in the cave passage is also observed in the external cliff face. The epiphreatic stream flows towards NNW where it crosses the Lower Painted Cave (point 8). The overall orientation of the Upper Painted Cave is also NNW-SSE, suggesting that cave passages have been initiated along this predominant joint direction several times during karstification. The east limit of the tower also a similar orientation indicating that jointing also controls subaerial erosion around the tower and its breakdown pattern. Some of the breakdown is enhanced by mechanical action of plant roots within joints.

Although the Niah karst is quite small, many of the relict caves are large with passages over $50 \mathrm{~m}$ diameter being quite common. The presence of such large fossil caves is evidence of significant karstification in the past due to high flow rates, aggressive dissolution and/or long periods of formation, as well as ceiling breakdown. The large caves are believed to be formed by point-recharge from sinking streams draining regional non-karst catchments (Dodge-Wan 2017) during karstification phases 3 (middle Pleistocene) and 4 (late Pleistocene) identified by Wall (1967). The much smaller epiphreatic passages are inferred to be the result of on-going karstification that occurred since sea level attained its present level during the last 17,000 years during phase 5 (Wall 1967) and are related to limited local runoff.

\section{HYDROGEOCHEMISTRY}

The results of chemical analysis of stream water samples are given in Tab. 1 with samples numbered from upstream to downstream sampling points as shown in Fig. 1. The $\mathrm{pH}$ index of the stream water was uniform and ranged between 7.03 and 7.30 with an average of 7.10. The values show that the stream water is close to neutral at the time of sampling which was during low flow to drought condition. It is interesting to note that the two highest $\mathrm{pH}$ values were at the downstream end of the stream after its exit from the karst tower, while the lowest values were in the middle and upstream. However, there is no clear progressive upstream to downstream trend. Eh (oxidation - reduction potential) values ranged from $3.1 \mathrm{mV}$ to $17.2 \mathrm{mV}$. Samples 9 and 10 (downstream) differ from the others in having the two lowest Eh values (3.1 and $4.2 \mathrm{mV}$ respectively). The other samples range from 10.4 to $17.2 \mathrm{mV}$ with an average of $14.4 \mathrm{mV}$. There is an inverse relation observed between $\mathrm{pH}$ and Eh. Overall the Eh values are low indicating low-oxidizing condition of the stream water particularly at the downstream (Prasanna et al. 2014b). Dissolved oxygen (DO) concentration ranges from $2.2 \mathrm{mg} / \mathrm{l}$ to $3.8 \mathrm{mg} / \mathrm{l}$ with an average of $2.8 \mathrm{mg} / \mathrm{l}$. The lowest dissolved oxygen values are observed in the middle section of the stream (sample points 4 to 7 ). The flow rate was qualified as slight in that sector. Electrical conductivity (EC) gives general information on water chemistry. In the Niah epiphreatic cave stream water, the EC values were very consistent ranging from $241 \mu \mathrm{S} / \mathrm{cm}$ to $458 \mu \mathrm{S} / \mathrm{cm}$ with an average of $265.8 \mu \mathrm{S} / \mathrm{cm}$. Only one sample (point 10) showed an anomalously high value of $458 \mu \mathrm{s} / \mathrm{cm}$ and this is thought to be related to anthro- 


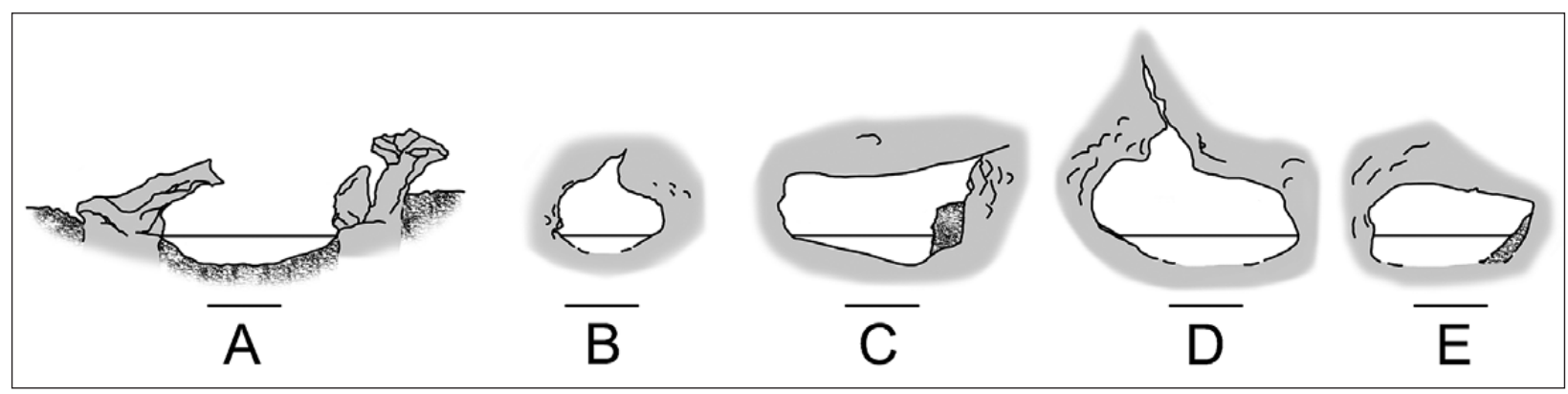

Fig. 5: Cross-sections of stream and typical epiphreatic cave passages, shown looking downstream with water levels as observed during drought conditions (March 2014). A) sampling point 1 in forest; B) sampling point 3; C) sampling point 4; D) sampling point 5; E) sampling point 8 in Lower Painted Cave. For all illustrations the scale bar is $1 \mathrm{~m}$, grey represents limestone and speckled hatching represents sediments.

Tab. 1: Chemical composition of the cave stream.

\begin{tabular}{|c|c|c|c|c|c|c|c|c|c|c|c|c|c|c|c|c|}
\hline $\begin{array}{l}\text { Sample } \\
\text { ID }\end{array}$ & $\begin{array}{l}\text { Temp } \\
\left({ }^{\circ} \mathrm{C}\right)\end{array}$ & $p H$ & $\begin{array}{l}E C \\
(\mu \mathrm{S} / \mathrm{cm})\end{array}$ & $\begin{array}{l}\text { TDS } \\
(\mathrm{mg} / \mathrm{l})\end{array}$ & $\begin{array}{l}\text { DO } \\
(m g / l)\end{array}$ & $\begin{array}{l}E h \\
(m V)\end{array}$ & $\begin{array}{l}\mathrm{Ca} \\
(\mathrm{mg} / \mathrm{l})\end{array}$ & $\begin{array}{l}M g \\
(m g / l)\end{array}$ & $\begin{array}{l}\mathrm{Cl} \\
(\mathrm{mg} / \mathrm{l})\end{array}$ & $\begin{array}{l}\mathrm{HCO} 3 \\
(\mathrm{mg} / \mathrm{l})\end{array}$ & $\begin{array}{l}\mathrm{NH3} \\
(m g \backslash \mathrm{l})\end{array}$ & $\begin{array}{l}\text { NO3 } \\
\text { (mgll) }\end{array}$ & $\begin{array}{l}\text { SO4 } \\
(m g \backslash)\end{array}$ & $\begin{array}{l}\text { PO4 } \\
\text { (mg/l) }\end{array}$ & IS & $\begin{array}{l}\log \\
p \mathrm{CO}_{2}\end{array}$ \\
\hline 1 & 25.8 & 7.16 & 247.5 & 121 & 3.8 & 10.4 & 26 & 1.2 & 26 & 115.9 & 0.34 & 0.11 & 46 & 0.10 & 0.0035 & -2.09 \\
\hline 2 & 25.7 & 7.03 & 246.7 & 121 & 3.0 & 17.2 & 26 & 2.4 & 6 & 109.8 & 0.43 & 0.08 & 52 & 0.23 & 0.0034 & -1.98 \\
\hline 3 & 26.3 & 7.10 & 248.0 & 122 & 2.6 & 13.4 & 26 & 6.0 & 14 & 103.7 & 0.26 & 0.12 & 49 & 0.11 & 0.0036 & -2.08 \\
\hline 4 & 25.4 & 7.04 & 244.7 & 120 & 2.4 & 16.6 & 24 & 1.2 & 14 & 103.7 & 0.26 & 0.07 & 51 & 0.13 & 0.0032 & -2.02 \\
\hline 5 & 26.0 & 7.05 & 241.6 & 118 & 2.5 & 16.0 & 30 & 1.2 & 46 & 97.6 & 0.28 & 0 & Ju & 0.10 & 0.0039 & -2.06 \\
\hline 6 & 25.2 & 7.08 & 241.5 & 118 & 2.4 & 14.3 & 22 & 2.4 & 26 & 103.7 & 0.27 & 0.08 & 50 & 0.15 & 0.0034 & -2.06 \\
\hline 7 & 25.4 & 7.04 & 241.3 & 118 & 2.2 & 16.4 & 22 & 1.2 & 18 & 109.8 & 0.28 & 0.11 & 49 & 0.11 & 0.0032 & -1.99 \\
\hline 8 & 25.5 & 7.14 & 45.0 & 120 & 2.8 & 11.2 & 22 & 2.4 & 26 & 91.5 & 0.26 & 0.09 & 46 & 0.09 & 0.0032 & -2.17 \\
\hline 9 & 25.3 & 7.30 & 243.4 & 119 & 3.3 & 3.1 & 22 & 3.6 & 22 & 85.4 & 0.26 & 0.14 & 44 & 0.11 & 0.0032 & -2.37 \\
\hline 10 & 25.5 & 7.28 & 458.0 & 224 & 3.0 & 4.2 & 22 & 1.2 & 10 & 91.5 & 0.20 & 0.15 & 47 & 0.08 & 0.0029 & -2.31 \\
\hline
\end{tabular}

pogenic pollution at this site which is used by local bird nest harvesters for washing and bathing.

$\mathrm{Ca}^{2+}$ is the dominant cation and ranged from $22 \mathrm{mg} / \mathrm{l}$ to $30 \mathrm{mg} / \mathrm{l}$ with an average of $24 \mathrm{mg} / \mathrm{l}$. The $\mathrm{Mg}^{2+}$ content was between $1.2 \mathrm{mg} / \mathrm{l}$ and $6 \mathrm{mg} / \mathrm{l}$ with an average of $2.3 \mathrm{mg} / \mathrm{l}$. No clear upstream to downstream trend was observed for either $\mathrm{Ca}^{2+}$ or $\mathrm{Mg}^{2+}$ (Fig. 6). $\mathrm{HCO}_{3}^{-}$is the dominant anion and ranged between $85.4 \mathrm{mg} / \mathrm{l}$ and $115.9 \mathrm{mg} / \mathrm{l}$ with an average of $101.3 \mathrm{mg} / \mathrm{l}$. Overall, $\mathrm{HCO}_{3}^{-}$ concentration decreases along the stream flow path although the trend is tentative. There is a slight increase of $\mathrm{HCO}_{3}^{-}$values at the midstream, where the flow condition was noted to be very slow. This would be expected for possible water-rock interaction due to the increase in residence time, where the water in contact with limestone brings more $\mathrm{HCO}_{3}^{-}$content (i.e. Prasanna et al. 2014a).

The $\mathrm{pH}$ values at these locations were also lower, which supports the easy dissolution of carbonate minerals (Stumm \& Morgan 1981; Khanaqa \& Al-Manmi 2011). Similar trend was also observed for $\mathrm{Ca}^{2+}$ concentration. $\mathrm{Cl}^{-}$content ranged between $6 \mathrm{mg} / \mathrm{l}$ and $46 \mathrm{mg} / \mathrm{l}$ with an average of $20.8 \mathrm{mg} / \mathrm{l} \mathrm{Cl}{ }^{-}$in the stream water may results from the atmospheric contribution (Mayer 1999) or from various sources of pollution (Neill et al. 2004). $\mathrm{Ca}^{2+}$ and $\mathrm{HCO}_{3}^{-}$are the most dominant ions in the samples indicating that the stream water is of $\mathrm{Ca}-\mathrm{HCO}_{3}$ type as would be expected predominantly in limestone rock of this karst environment.

$\mathrm{SO}_{4}^{2-}$ ion concentrations ranged from 44 to $52 \mathrm{mg} / \mathrm{l}$ with a tentative trend of decreasing $\mathrm{SO}_{4}^{2-}$ concentration along the epiphreatic stream. $\mathrm{SO}_{4}^{2-}$ ion can originate from the leaching of clay minerals present at the bottom sediments of the stream (Prasanna et al. 2012). The inverse relationship between $\mathrm{pH}$ and $\mathrm{SO}_{4}^{2-}$ indicates the near acidic water might dissolve the clay minerals, which increase the $\mathrm{SO}_{4}^{2-}$ content in the stream water (Fig. 7). Positive correlation between $\mathrm{Eh}$ and $\mathrm{SO}_{4}^{2-}$ also indicates the oxidation of clay minerals for the increase of $\mathrm{SO}_{4}^{2-}$ (Tab. 2). $\mathrm{NH}_{3}$ concentrations ranged from 0.20 to $0.43 \mathrm{mg} / \mathrm{l}$ with most values around $0.26 \mathrm{mg} / \mathrm{l}$. The two highest values were observed only at the upstream sampling points 1 and 2. The source of $\mathrm{NH}_{3}$ may be from the reduction of nitrate in existing of organic mat- 


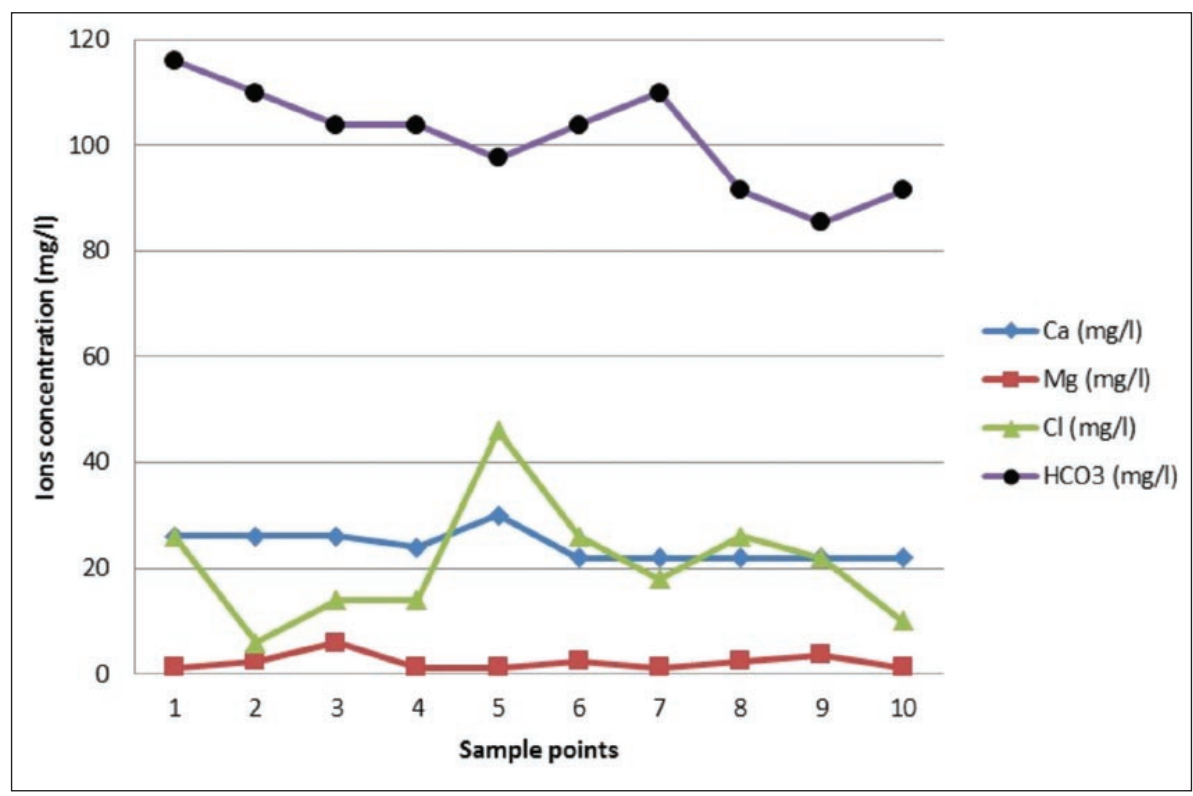

Fig. 6: Spatial trend of major ions chemistry of cave stream from upstream to downstream.

ter (Khanaqa \& Al-Manmi 2011). $\mathrm{NO}_{3}^{-}$concentrations ranged from 0.07 to $0.15 \mathrm{mg} / \mathrm{l}$ with the highest values at the downstream sampling points 9 and 10. The concentration of $\mathrm{NO}_{3}^{-}$can be derived from the degradation of organic matters in the soil and also from the soil leachate (e.g. Prasanna et al. 2014a). pH shows good correlation with $\mathrm{EC}, \mathrm{TDS}, \mathrm{DO}$ and $\mathrm{NO}_{3}{ }^{-}$and it indicates the dissolution of organic matter in the bottom sediments, which increase the $\mathrm{NO}_{3}{ }^{-}$content in the stream water (Tab. 2). $\mathrm{PO}_{4}^{3-}$ ranges from $0.08 \mathrm{mg} / \mathrm{l}$ to $0.23 \mathrm{mg} / \mathrm{L}$ with no clear upstream to downstream trend. The concentration of $\mathrm{PO}_{4}^{3-}$ may be derived from the degradation of organic matter (Hutchinson 1950; Karkanas 2001).
The principal component analysis (PCA) was performed to further explore and identify the source of ions in the stream water. Five factors were extracted for major ions and nutrients data set with eigenvalues $>1$ (Tab. 3). The eigenvalue for a given factor measures the variance in all the variables which is accounted for by that factor. In general, the factor will be related to the largest eigenvalue and the greatest amount of variance in the data set (Davis 1986). The contribution of a factor is said to be significant when the corresponding eigenvalue is greater than unity (Briz-Kishore \& Murali 1992). PC1 is loaded with $\mathrm{HCO}_{3}^{-}, \mathrm{NH}_{3}$ and $\mathrm{PO}_{4}^{3-}$ suggesting that these parameters are related to the leaching and dissolution of organ-

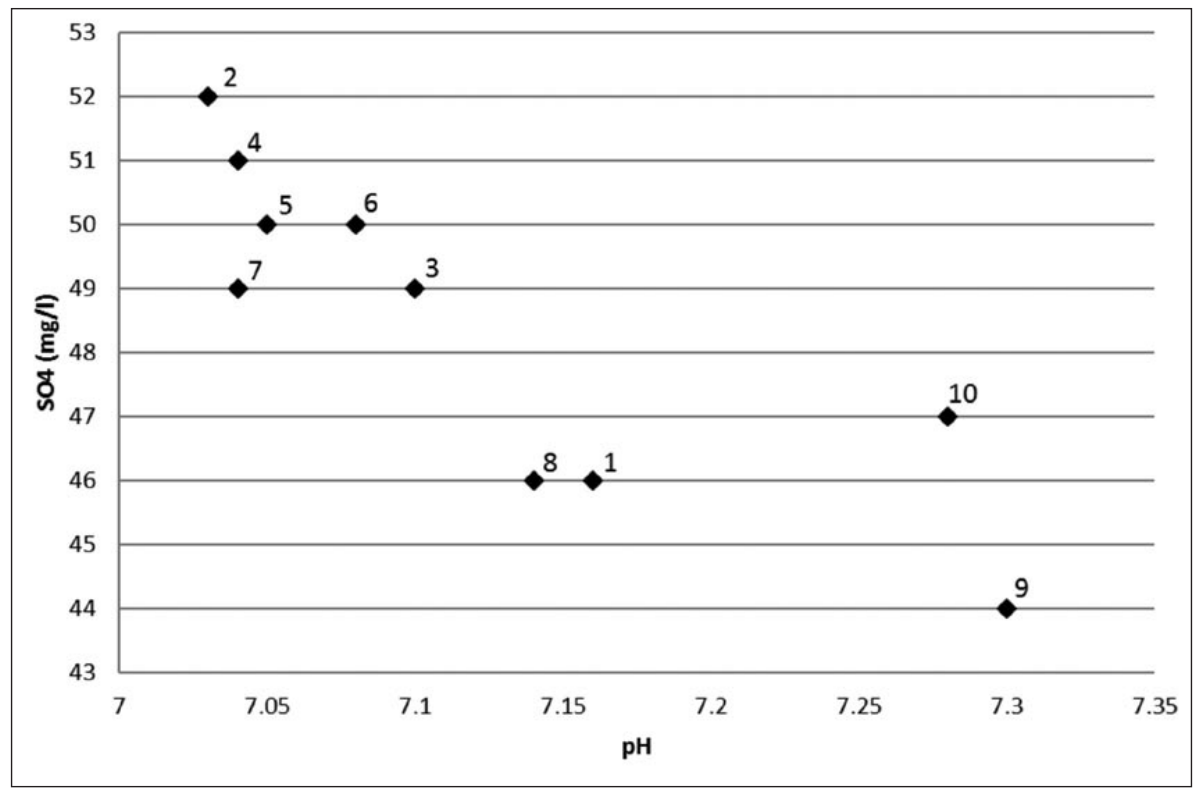

Fig. 7: Relationship between $\mathrm{pH}$ and $\mathrm{SO}_{4}$ (numbers near the points indicate sample ID). 


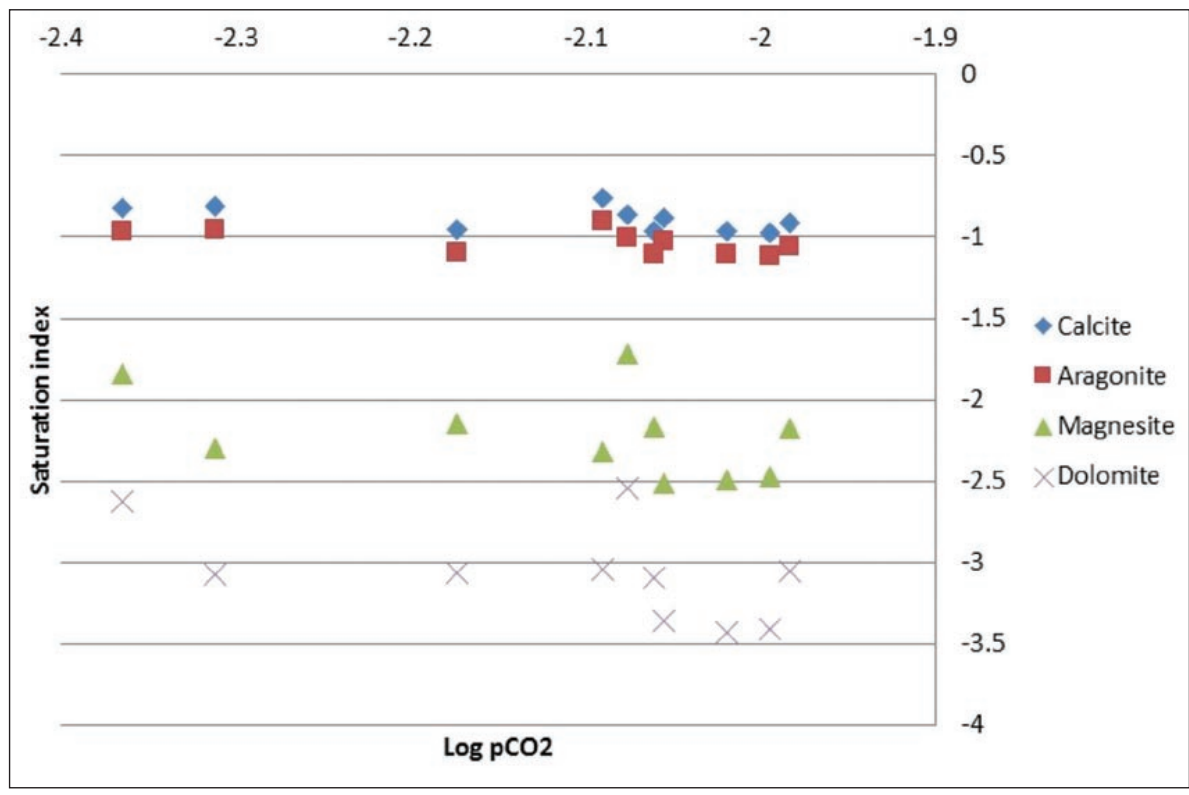

Fig. 8: $\log \mathrm{pCO}_{2}$ vs. SI of carbonate minerals.

Tab. 2: Correlation analysis for major ions and nutrients.

\begin{tabular}{l|r|r|r|r|r|r|r|r|r|r|r|l|l|l}
\hline & Temperature & \multicolumn{1}{c|}{$\mathrm{pH}$} & $\mathrm{EC}$ & $\mathrm{TDS}$ & $\mathrm{DO}$ & $\mathrm{Eh}$ & $\mathrm{Ca}$ & $\mathrm{Mg}$ & $\mathrm{Cl}$ & $\mathrm{HCO}_{3}$ & $\mathrm{NH}_{3}$ & $\mathrm{NO}_{3}$ & $\mathrm{SO}_{4}$ & $\mathrm{PO}_{4}$ \\
\hline Temperature & 1.000 & & & & & & & & & & & & \\
\hline $\mathrm{pH}$ & -.221 & 1.000 & & & & & & & & & & & \\
\hline $\mathrm{EC}$ & -.093 & .565 & 1.000 & & & & & & & & & & \\
\hline $\mathrm{TDS}$ & -.089 & .564 & 1.000 & 1.000 & & & & & & & & & & \\
\hline $\mathrm{DO}$ & .100 & .611 & .165 & .164 & 1.000 & & & & & & & & & \\
\hline $\mathrm{Eh}$ & .228 & -1.000 & -.560 & -.559 & -.602 & 1.000 & & & & & & & & \\
\hline $\mathrm{Ca}$ & .781 & -.429 & -.273 & -.273 & .067 & .438 & 1.000 & & & & & & & \\
\hline $\mathrm{Mg}$ & .433 & .133 & -.230 & -.225 & .000 & -.136 & .006 & 1.000 & & & & & & \\
\hline $\mathrm{Cl}$ & .141 & -.093 & -.352 & -.357 & -.064 & .084 & .438 & -.223 & 1.000 & & & & & \\
\hline $\mathrm{HCO}$ & .256 & -.650 & -.346 & -.345 & .000 & .656 & .329 & -.186 & -.154 & 1.000 & & & & \\
\hline $\mathrm{NH}_{3}$ & .194 & -.468 & -.467 & -.466 & .296 & .478 & .417 & -.051 & -.152 & .625 & 1.000 & & & \\
\hline $\mathrm{NO}_{3}$ & .252 & .695 & .535 & .533 & .308 & -.695 & .065 & .120 & .178 & -.483 & -.456 & 1.000 & & \\
\hline $\mathrm{SO}_{4}$ & .174 & -.852 & -.196 & -.193 & -.608 & .857 & .401 & -.122 & -.166 & .514 & .400 & -.576 & 1.000 & \\
\hline $\mathrm{PO}_{4}$ & -.076 & -.500 & -.329 & -.327 & -.069 & .508 & .149 & .082 & -.407 & .415 & .795 & -.601 & .654 & 1.000 \\
\hline
\end{tabular}

ic matter. PC2 is loaded with $\mathrm{pH}$ and $\mathrm{DO}$, indicates the oxidizing condition of stream water. PC3 is loaded with EC and TDS as would be expected as both parameters are an indicator of the total mineralization of the stream water. PC4 and PC5 are loaded with temperature, $\mathrm{Ca}^{2+}$ and $\mathrm{Mg}^{2+}$ reflecting the dissolution of limestone.

All stream water samples show low ionic strength values between 0.00292 and 0.00389 i.e. below the standard of $<0.005$, ionic strength of fresh water indicates newly recharged water entering the cave system from a low mineralization allogeneic source (i.e. Prasanna et al. 2014a) and not showing a significant trend of increasing mineralization during its transit through the karst.
Log $\mathrm{pCO}_{2}$ is a very significant parameter for carbonate rock dissolution in meteoric water (Jeelani et al. 2011). Higher $\log \mathrm{pCO}_{2}$ values are observed in the upstream and midstream suggesting that additional $\mathrm{CO}_{2}$ has been obtained from the sediments during water-rock interaction (i.e. Chidambaram et al. 2011). The lowest $\mathrm{pCO}_{2}$ values were observed in the downstream (sample points 9 and 10) slightly less than the atmospheric value of -3.5 , indicating that the residence time of these water is considerably lesser, also perhaps mixing with additional fresh recharge water from other sources. The hydrogeochemistry reveals that the overall water is not very aggressive. 
Tab. 3: Factor analysis for major ions and nutrients.

\begin{tabular}{l|r|r|r|r|r}
\hline & \multicolumn{5}{|c}{ Component } \\
\hline & Factor 1 & Factor 2 & Factor 3 & Factor 4 & Factor 5 \\
\hline Temperature & .027 & -.042 & .016 & .925 & .316 \\
\hline $\mathrm{pH}$ & -.396 & .797 & .356 & -.224 & .136 \\
\hline $\mathrm{EC}$ & -.227 & .174 & .943 & -.066 & -.111 \\
\hline $\mathrm{TDS}$ & -.224 & .171 & .945 & -.065 & -.104 \\
\hline $\mathrm{DO}$ & .274 & .929 & .064 & .149 & -.079 \\
\hline $\mathrm{Eh}$ & .409 & -.793 & -.348 & .231 & -.137 \\
\hline $\mathrm{Ca}$ & .156 & -.127 & -.182 & .917 & -.135 \\
\hline $\mathrm{Mg}$ & -.065 & .082 & -.161 & .151 & .959 \\
\hline $\mathrm{Cl}$ & -.519 & .031 & -.557 & .368 & -.447 \\
\hline $\mathrm{HCO}_{3}$ & .680 & -.265 & -.141 & .275 & -.226 \\
\hline $\mathrm{NH}_{3}$ & .890 & .066 & -.290 & .234 & -.073 \\
\hline $\mathrm{NO}_{3}$ & -.560 & .492 & .399 & .335 & .072 \\
\hline $\mathrm{SO}_{4}$ & .467 & -.830 & .060 & .193 & -.050 \\
\hline $\mathrm{PO}_{4}$ & .848 & -.256 & -.100 & -.095 & .162 \\
\hline
\end{tabular}

Tab. 4: Metal concentration in the cave stream.

\begin{tabular}{l|l|l|l|l|l|l|l|l}
\hline $\begin{array}{l}\text { Sample } \\
I D\end{array}$ & $\begin{array}{l}\mathrm{Cu} \\
(\mathrm{mg} / \mathrm{l})\end{array}$ & $\begin{array}{l}\mathrm{Pb} \\
(\mathrm{mg} / \mathrm{l})\end{array}$ & $\begin{array}{l}F e \\
(\mathrm{mg} / \mathrm{l})\end{array}$ & $\begin{array}{l}\mathrm{Mn} \\
(\mathrm{mg} / \mathrm{l})\end{array}$ & $\begin{array}{l}\mathrm{Zn} \\
(\mathrm{mg} / \mathrm{l})\end{array}$ & $\begin{array}{l}\mathrm{Cd} \\
(\mathrm{mg} / \mathrm{l})\end{array}$ & $\begin{array}{l}\mathrm{Ni} \\
(\mathrm{mg} / \mathrm{l})\end{array}$ & $\begin{array}{l}\mathrm{Co} \\
(\mathrm{mg} / \mathrm{l})\end{array}$ \\
\hline 1 & 0.068 & 0.099 & 1.131 & 0.099 & 0.041 & 0.001 & 0.021 & 0.011 \\
\hline 2 & 0.056 & 0.101 & 0.884 & 0.079 & 0.03 & $\mathrm{BDL}$ & 0.023 & $\mathrm{BDL}$ \\
\hline 3 & 0.057 & 0.095 & 1.131 & 0.09 & 0.036 & 0.001 & 0.014 & 0.013 \\
\hline 4 & 0.058 & 0.093 & 1.158 & 0.098 & 0.05 & 0.001 & 0.024 & 0.018 \\
\hline 5 & 0.037 & 0.094 & 1.055 & 0.097 & 0.028 & 0.001 & 0.03 & 0.004 \\
\hline 6 & 0.046 & 0.096 & 1.19 & 0.11 & 0.039 & 0.001 & 0.022 & 0.003 \\
\hline 7 & 0.052 & 0.098 & 1.082 & 0.101 & 0.032 & 0.005 & 0.024 & 0.02 \\
\hline 8 & 0.044 & 0.094 & 1.011 & 0.112 & 0.041 & $\mathrm{BDL}$ & 0.015 & $\mathrm{BDL}$ \\
\hline 9 & 0.049 & 0.099 & 1.108 & 0.108 & 0.024 & $\mathrm{BDL}$ & 0.025 & 0.004 \\
\hline 10 & 0.045 & 0.098 & 1.22 & 0.151 & 0.036 & $\mathrm{BDL}$ & 0.003 & 0.003 \\
\hline
\end{tabular}

Saturation indices were calculated for carbonate minerals (Calcite, Aragonite, Magnesite and Dolomite). The water was found to be under-saturated for all the carbonate minerals indicating the potential for further dissolution of the limestone. High dissolution of minerals is observed in the upstream side with higher $\log \mathrm{pCO}_{2}$ values due to the longer residence time of the water with the host rock and soil cover (Fig. 8). Overall there is no spatial trend of increasing saturation from upstream to downstream. This may be due to the short length of the flow path (approximately $500 \mathrm{~m}$ ) in the cave region or due to the geological complexities in the dissolution at specific sites and uncertain subsurface structures.
Tab. 5: Correlation for metals concentration

\begin{tabular}{l|l|l|l|l|l|l|l|l}
\hline & $\mathrm{Cu}$ & $\mathrm{Pb}$ & $\mathrm{Fe}$ & $\mathrm{Mn}$ & $\mathrm{Zn}$ & $\mathrm{Cd}$ & $\mathrm{Ni}$ & $\mathrm{Co}$ \\
\hline $\mathrm{Cu}$ & 1.000 & & & & & & & \\
\hline $\mathrm{Pb}$ & .345 & 1.000 & & & & & & \\
\hline $\mathrm{Fe}$ & .012 & -.290 & 1.000 & & & & & \\
\hline $\mathrm{Mn}$ & -.406 & -.030 & .622 & 1.000 & & & & \\
\hline $\mathrm{Zn}$ & .390 & -.512 & .366 & .093 & 1.000 & & & \\
\hline $\mathrm{Cd}$ & .118 & .000 & .081 & -.180 & -.030 & 1.000 & & \\
\hline $\mathrm{Ni}$ & .008 & -.053 & -.371 & -.698 & -.254 & .294 & 1.000 & \\
\hline $\mathrm{Co}$ & .509 & -.211 & .333 & -.235 & .358 & .740 & .184 & 1.000 \\
\hline
\end{tabular}

Tab. 6: Factor analysis for metals concentration.

\begin{tabular}{l|c|c|c|c}
\hline & \multicolumn{4}{|c}{ Component } \\
\hline & Factor 1 & Factor 2 & Factor 3 & Factor 4 \\
\hline $\mathrm{Cu}$ & -.111 & .173 & -.127 & .960 \\
\hline $\mathrm{Pb}$ & .007 & -.070 & -.948 & .251 \\
\hline $\mathrm{Fe}$ & .762 & .321 & .321 & .034 \\
\hline $\mathrm{Mn}$ & .920 & -.110 & -.008 & -.295 \\
\hline $\mathrm{Zn}$ & .240 & .000 & .730 & .561 \\
\hline $\mathrm{Cd}$ & -.105 & .938 & -.078 & -.034 \\
\hline $\mathrm{Ni}$ & -.823 & .306 & .044 & -.172 \\
\hline $\mathrm{Co}$ & -.017 & .854 & .241 & .404 \\
\hline
\end{tabular}

The trace metals do not show significant spatial variance in their concentration along the stream. Iron $(\mathrm{Fe})$ and manganese $(\mathrm{Mn})$ show higher concentrations than the other metals (Tab. 4). Fe and Mn could be derived from the leaching of soil materials to the water (i.e. Prasanna et al. 2012). At near-neutral $\mathrm{pH}$ condition, the solubility of Fe and Mn minerals are strongly redox controlled (Lorite-Herrera et al. 2008). A significant correlation has also been observed between $\mathrm{Fe}$ and $\mathrm{Mn}$. Co is correlated with $\mathrm{Cu}$ and $\mathrm{Cd}$ indicates the leaching of metals from the soil and the host rock (Tab. 5). PCA was also applied for the trace metals data for the source identification. PC1 is highly loaded with Fe and Mn explains the similar sources reported in the correlation analysis (Tab. 6). PC2, PC3 and PC4 are loaded with Cd, Co, Zn and $\mathrm{Cu}$ and could be ascribed from the geochemistry of host rock and the soil cover (Motyka et al. 2005). 


\section{CONCLUSIONS}

The study has identified previously unknown epiphreatic passages in the Niah tower karst. It has mapped a small diameter epiphreatic passage in the Painted Cave karst tower, and established that it receives recharge from a minor allogenic stream from the east of the tower. The passage is not a direct one through the hill, but follows a contorted path following joint directions. In places breakdown of the tower has revealed the former underground stream to the daylight. The location of current epiphreatic passages is controlled by the current water level and by the jointing of the limestone with over $50 \%$ of the passages following predominant jointing in NNW-SSE orientation. The epiphreatic passage cuts across a large relict vadose passage of the Lower Painted Cave and is the most recent and on-going phase of multi-level karstification, perhaps being the only currently known evidence of present day active karst dissolution passages. The known relict cave passages at higher levels in the karst tower, such as the Upper Painted Cave may have formed along similar joint directions under very different flow conditions in the past. The presence of a swamp notch approximately $2 \mathrm{~m}$ above current ground level formed in the recent geological past and not yet modified by bioerosion acting on stylolites suggests that relative base level drop is on-going and proceeding in a step-like manner.

The results of hydrochemical analysis showed that the $\mathrm{pH}$ of epiphreatic karst stream water is close to neutral during very low flow drought condition. $\mathrm{Ca}^{2+}$ and $\mathrm{HCO}_{3}^{-}$are the dominant ions, represented $\mathrm{Ca}-\mathrm{HCO}_{3}$ water type which indicates the dissolution of carbonate minerals. The concentration of $\mathrm{SO}_{4}^{2-}$ was controlled by the oxidation and leaching of clay minerals in the stream sediments. $\mathrm{NO}_{3}^{-}$and $\mathrm{PO}_{4}^{3-}$ content in the cave stream were derived from the leaching of organic matter from the bottom sediments or within the environment. The results of mineral saturation index show under-saturation conditions for all carbonate minerals for all the samples, indicating potential for rock dissolution. Higher log $\mathrm{pCO}_{2}$ values in the upstream side also reveal greater potential for dissolution of minerals from the host rock and sediments. Most of the metal contents in the cave stream were mainly controlled by the geochemistry of limestone and sediments. Overall, the stream water has low mineralization and no clear upstream to downstream trend of ionic concentration was observed. The aquifer water quality at the water table surface is fairly homogenous and similar to that of the allogenic source entering the karst on the east during drought season. There is evidence for both phreatic and vadose dissolution as would be expected at water table. The geochemical results and the passage morphology suggest that the majority of dissolution occurs during flood conditions. Further sampling and testing during medium to flood conditions is warranted to confirm this. It would also be advantageous to measure flow rates during wet conditions, although access to the confined underground sites should not be attempted due to flooding risk. In addition, measurement of wall scallops in the epiphreatic passages would be of interest to provide an indication of flow velocity during flood conditions. Further investigations for caves at the foot of other karst towers in this and other regions would be worth undertaking to gain perspective on the regional distribution of similar karst solution features.

\section{ACKNOWLEDGMENTS}

The authors thank the Sarawak Forest Department for permission to conduct research under permit (Permit No NCCD.907.4.4 (Jld.9)-61 and Park permit No. 120/2013). MVP is thankful to Curtin University Malaysia for financial support through the CSRCF Project (CSRCF 5006).
Pengarah, Jabatan Meterologi Malaysia, Cawangan Sarawak is gratefully acknowledged for providing rainfall data from Niah forest office. Thanks also to Curtin University Applied Geology students (2011) for assistance in field surveys. 


\section{REFERENCES}

APHA (American Public Health Association), 1995: Standard methods for the examination of water and wastewater.- APHA, pp. 1467, Washington, DC.

Ball, J.W. \& K. Nordstrom, 2001: User's manual for WATEQ4F, with revised thermodynamic data base and test cases for calculating speciation of major, trace, and redox elements in natural waters.- U.S Geological Survey, Open-file Report 91-183.

Barker, G., Barton, H., Bird, M., Daly, P., Datan, I., Dykes, A., Farr, I., Gilbertson, D., Harrisson, B., Hunt, C., Higham, T., Kealhofer, I., Krigbaum, J., Lewis, H., Mclaren. S., Paz, V., Pike. A., Piper, P., Pyatt, B., Rabett, R., Reynolds, T., Rose, J., Rushworth, G., Stephens. M., Stringer, C., Thompson, J. \& C. Turney, 2007: The 'human revolution' in lowland tropical Southeast Asia: the antiquity and behavior of anatomically modern humans at Niah Cave (Sarawak, Borneo).- Journal of Human Evolution, 52, 3, 243-261. DOI: https://doi.org/10.1016/j. jhevol.2006.08.011.

Borsato, A., 1997: Dripwater monitoring at Grata di Ernesto (NE-Italy). A contribution to the understanding of karst and kinetics of carbonate dissolution.- In: Jeannin, P.-Y. (ed.) Proceedings of the $12^{\text {th }}$ international congress of speleology, $10^{\text {th }}-17^{\text {th }}$ August 1997, La Chaux-de-Fonds. Speleo Projects, 57-60, Basel.

Briz-Kishore, B.H. \& G. Murali, 1992: Factor analysis for revealing hydrogeochemical characteristics of watersheds.- Environmental Geology and Water Sciences, 9, 3-9.

Chidambaram, S., Prasanna, M.V., Karmegam, U., Singaraja, C., Pethaperumal, S., Manivannan, R., Anandhan, P. \& K. Tirumalesh, 2011: Significance of $\mathrm{pCO}_{2}$ values in determining carbonates chemistry in groundwater of Pondicherry region, India.- Frontiers of Earth Science, 5, 2, 197-206. DOI: https:// doi.org/10.1007/s11707-011-0170-5.

Chidambaram, S., Prasanna, M.V., Singaraja, C., Thilagavathi, R., Pethaperumal, S. \& K. Tirumalesh, 2012: Study on the saturation index of the carbonates in the groundwater using WATEQ4F in layered coastal aquifers of Pondicherry.- Journal of the Geological Society of India, 80, 6, 813-824. DOI: https://doi. org/10.1007/s12594-012-0210-0.

Davis, J.C., 1986: Statistics and data analysis in geology.John Wiley \& Sons, pp. 656, New York.
Dodge-Wan, D., Deng, A.H.M. \& M.F. Abbas, 2012: Occurrence and morphology of crayback-like stalagmites in the Painted Cave of Niah (Sarawak, Malaysia).- Carbonates and Evaporites, 27, 3-4, 343-356. DOI: https://doi.org/10.1007/s13146-012-0117-2.

Dodge-Wan, D. \& A.H.M. Deng, 2013: Biologically influenced stalagmites in Niah and Mulu caves (Sarawak, Malaysia).- Acta Carsologica, 42, 1, 155-163. DOI: http://dx.doi.org/10.3986/ac.v42i1.634.

Dodge-Wan D., 2017: The Traders' Cave of Niah (NW Borneo): morphology and features as indicators of speleogenesis and karstification.- Carbonates and Evaporites, In Press, 1-15. DOI: http://dx.doi. org/10.1007/s13146-017-0357-2.

Farrant, A.R., Smart P.L, Whitaker F.F. \& D.H. Tarling, 1995: Long-term Quaternary uplift rates inferred from limestone caves in Sarawak, Malaysia.- Geology, 23, 4, 357-360. DOI: https://doi.org/10.1130/00917613(1995)023<0357:LTQURI>2.3.CO;2.

Ford, D.C. \& R.O. Ewers, 1978: The development of limestone cave systems in the dimensions of length and depth.- Canadian Journal of Earth Sciences, 15, 11, 1783-1798. DOI: https://doi.org/10.1139/e78-186

Ford, D.C. \& P.W. Williams, 2007: Karst Hydrogeology and Geomorphology.- John Wiley and Sons, pp. 562, England.

Frumkin, A., 2013: New developments of karst geomorphology concepts.- In: Shroder, J.F. (ed.) Treatise on Geomorphology. Academic Press, pp. 6386, San Diego.

Gabrovšek, F., Häuselmann, P. \& P. Audra, 2014: 'Looping caves' versus 'water table caves': the role of baselevel changes and recharge variations in cave development.- Geomorphology, 204, 683-691. DOI: https://doi.org/10.1016/j.geomorph.2013.09.016.

Goc, P., Gorny, A., Klojzy-Karczmarczyk, B. \& J. Motyka, 2000: Nitrates in cave waters of southern part of Cracow upland (in polish, english summary). Prace naukowe uniwersytetu slaskiego 1922.- Kras I Speleogia, 10, 67-83.

Gonzales, L.A., Carpenter, S.J. \& K.C. Lohmann, 1992: Inorganic calcite morphology: roles of fluid chemistry and fluid flow.- Journal of Sedimentary Petrology, 62, 382-399.

Häuselmann, P., 2011: UIS Mapping Grades.- [Online]. Available from: http://scholarcommons.usf.edu/ijs/ vol40/iss2/15 [Accessed 27th june 2013].

Holland, H.D., Kirsipu, T.V., Huebner, J.S. \& U.M. Oxburgh, 1964: On some aspects of the chemical evolution of cave waters.- Journal of Geology, 72, 1, 481-492. DOI: https://doi.org/10.1086/626964. 
Hutchinson, G.E., 1950: Survey of contemporary knowledge of biogeochemistry: 3. The biogeochemistry of vertebrate excretion.- Bulletin of the American Museum of Natural History, vol. 96, pp. 554, New York.

Hutchison, C.S., 2005: Geology of North-West Borneo.Elsevier Science, pp. 444, Amsterdam.

Jeelani, G., Bhat, N.A., Shivanna, K. \& M.Y. Bhat, 2011: Geochemical characterization of surface water and spring water in SE Kashmir Valley, western Himalaya: Implications to water-rock interaction.- Journal of Earth System Sciences, 120, 5, 921-932. DOI: https://doi.org/10.1007/s12040-011-0107-0.

Karkanas, P., 2001: Site formation processes in Theopetra Cave: a record of climatic change during the late Pleistocene and early Holocene in Thessaly, Greece.Geoarchaeology, 16, 4, 373-399. DOI: https:/doi. org/10.1002/gea.1009.

Khanaqa, P.A. \& D.A. Al-Manmi, 2011: Hydrogeochemistry and Geomicrobiology of Darzila spring in Sangaw, Sulaimaniyah, NE Iraq.- Iraqi Bulletin of Geology and Mining, 7, 3, 63-79.

Kogovsek, J., 1997: Pollution transport in the vadose zone. An example from Postojnska jama-Slovenia.In: Gunay, G. \& A.I. Johnson (eds.) Karst waters of environmental impacts: Proceedings of the $5^{\text {th }}$ international symposium and field seminar, $10^{\text {th }}-20^{\text {th }}$ September 1995, Antalya. Balkema, 161-165, Rotterdam.

Leh, C. \& S.L. Kheng, 2001: The swiftlet population of Niah Caves.- Sarawak Museum Journal, 56 (77 new series), 287-298.

Lorite-Herrera, M., Jiménez-Espinosa, R., Jiménez-Millán, J. \& K.M. Hiscock, 2008: Integrated hydrochemical assessment of the quaternary alluvial aquifer of the Guadalquivir River, southern Spain.- Applied Geochemistry, 23, 8, 2040-2054. DOI: https://doi. org/10.1016/j.apgeochem.2008.03.013.

Lundberg, J. \& D.A. McFarlane, 2011: A note on the occurence of a crayback stalagmite at Niah caves, Borneo.- International Journal of Speleology, 40, 1, 39-43. DOI: http://dx.doi.org/10.5038/1827-806X.40.1.5.

Mayer, J., 1999: Spatial and temporal variation of groundwater chemistry in Pettyjohns cave, Northwest Georgia, USA.- Journal of Cave and Karst Studies, $61,3,131-138$.

Motyka, J., Gradzinski, M., Bella, P. \& P. Holubek, 2005: Chemistry of waters from selected caves in Slovakia - a reconnaissance study.- Environmental Geology, $48,6,682-692$.
Motyka, J.\& K. Rozkowski, 2002: Concentration of selected ions in water percolating through Jurassic Carboniferous formation.- In: Gabrovšek, F. (ed.) Evolution of karst: from prekarst to cessation. ZRC Publishing, 383-386, Ljubljana.

Motyka, J., Rozkowski, K. \& A. Gorny, 2001: Results of tracers experiments in the zone of aeration in limestones of Zakrzowek Horst (Cracow, S Poland).- In: Mudry, J. \& F. Zwahlen (eds.) Proceedings of the $7^{\text {th }}$ Conference on Limestone Hydrology and Fissured Media, 20 ${ }^{\text {th }}-22^{\text {nd }}$ September 2001, Besancon. Faculté des Sciences, 257-260, Besancon.

Motyka, J., Rozkowski, K., Sikora, W. \& J. Goc, 2002: Influence of the unsaturated zone in Upper Jurassic limestones on the chemistry of groundwater (Ojcow National Park, Southern Poland) (in polish, english summary).- Biuletyn panstwowego instytutu geologicznego, 404, 123-144.

Musgrove, M. \& J.I. Banner, 2004: Controls on the spatial and temporal variability of vadose dripwater geochemistry: Edwards Aquifer, Central Texas.- Geochimica et Cosmochimica Acta, 68, 5, 1007-1020. DOI: https://doi.org/10.1016/j.gca.2003.08.014

Neill, H., Gutiérrez, M. \& T. Aley, 2004: Influences of agricultural practices on water quality of Tumbling Creek cave stream in Taney County, Missouri.- Environmental Geology, 45, 4, 550-559. DOI: https:// doi.org/10.1007/s00254-003-0910-2.

Palmer, A.N., 1991: Origin and morphology of limestone caves.- Geological Society of America Bulletin, 103, 1, 1-21. DOI: http://dx.doi.org/10.1130/0016-7606(1991)103<0001:OAMOLC>2.3.CO;2.

Prasanna, M.V., Nagarajan, R., Chidambaram, S., Manikandan, S. \& A. Elayaraja, 2014a: Drip water geochemistry of Niah Great Cave, NW Borneo, Malaysia: a base line study.- Carbonates and Evaporites, 29, 1, 41-54. DOI: https://doi.org/10.1007/s13146013-0164-3.

Prasanna, M.V., Nagarajan, R., Elayaraja, A. \& S. Chidambaram, 2014b: Preliminary investigation on electrochemical parameters of lake waters in and around Miri city, Malaysia.- Pertanika Journal of Science \& Technology, 22, 1, 329-335.

Prasanna, M.V., Praveena, S.M., Chidambaram, S., Nagarajan, R. \& A. Elayaraja, 2012: Evaluation of water quality pollution indices for heavy metal contamination monitoring: a case study from Curtin Lake, Miri City, East Malaysia.- Environmental Earth Sciences, 67, 7, 1987-2001. DOI: https://doi. org/10.1007/s12665-012-1639-6. 
Pyatt, F.B, Wilson, B. \& G.W. Barker, 2005: The chemistry of tree resins and ancient rock paintings in the Niah caves, Sarawak (Borneo): some evidence of rain forest management by early human populations.- Journal of Archaeological Science, 32, 6, 897-901. DOI: https://doi.org/10.1016/j.jas.2005.01.010.

Stephens, M., Rose, J. \& D.D. Gilbertson, 2017: Postdepositional alteration of humid tropical cave sediments: Micromorphological research in the Great Cave of Niah, Sarawak, Borneo.- Journal of Archaeological Science, 77, 109-124. DOI: https://doi. org/10.1016/j.jas.2016.01.015.

Stumm, W. \& J.J. Morgan, 1981: Aquatic Chemistry: An Introduction Emphasizing Chemical Equilibria in Natural Waters.- Environmental Science and Technology: A Wiley-Interscience Series of Texts and Monographs, Wiley, pp. 780, New York.
Tooth, A.F. \& I.J. Fairchild, 2003: Soil and karst aquifer hydrological controls on the geochemical evolution of speleothem-forming drip waters, Crag Cave, southwest Ireland.- Journal of Hydrology, 273, 1-4, 51-68. DOI: https://doi.org/10.1016/S0022-1694(02)00349-9.

Wall, J.R.D., 1967: Quaternary geomorphological history of north Sarawak with special reference to the Subis karst, Niah.- Sarawak Museum Journal, 15, 97-125. White, W.B., 1997: Thermodynamic equilibrium, kinetics, activation barriers, and reaction mechanisms for chemical reactions in Karst Terrains.- Environmental Geology, 30, 1-2, 46-58. DOI: https://doi. org/10.1007/s002540050131. 